\title{
EFFICIENCY AND CHARACTERIZATION OF AN ANTIBACTERIAL SECONDARY METABOLITE FROM ZINGBER OFFICINALE AGAINST AEROMONAS HYDROPHILA CAUSING AEROMONAS SEPTICEMIA IN TILAPIA NILOTICA ( OREOCHROMIS NILOTICUS ).
}

\author{
Bakry M. Haroun*, Esam H. Abd El - Shakour*, Mohmed E. Abou El - Atta**, Ahlam \\ E. abd latif*** , Fathy I. Abd Allah, El - Sayed M. Abd El-Hamid***
}

Botany and Microbiology Dep*t.- Al Azhar University (Boys) Cairo. Chief Researcher of fish Health. **. Animal Health Institute Zagazig***. Pharmaceutics and Industrial Pharmacy Dept., Faculty of Pharmacy (Boys), Al-Azhar University.****

\begin{abstract}
This study was conducted to isolate and identify Aeromonas hydrophila which is the causative agent of motile Aeromonas septicemia MAS in freshwater fish (Oreochromis niloticus) and to study the efficacy and characterization of an antibacterial agent from Zingber officinale against Aeromonas hydrophila in vitro which is causative agent of MAS.
\end{abstract}

This study was carried out using 100 O. niloticus weighting $80 \pm 5$ g Oreochromis niloticus were suffering from lose of appetite, lethargic, swim near the water surface, hemorrhage at the fins bases ulcer behind the head, roughness of scales (bristle out), slight distended abdomen and redness of anal opening. Internally the fish exhibited congestion of gills, liver, spleen, kidney and hemorrhage in peritoneal cavity, distended gall bladder, enlarged kidney and accumulation of serious fluid in abdominal cavity.

The bacteriological examination of the samples taken from clinically affected fish revealed the isolation of Aeromonas hydrophila. The incidence of infection in $O$. niloticus reach $58 \%$.

The experimental infection with the isolated Aeromonas hydrophila intraperitoneally resulted in $90 \%$ mortality in $O$. niloticus . The antibiogram sensitivity test revealed that ciprofloxacin in a dose of $5 \mathrm{mg}$ was highly effective in control of Aeromonas hydrophila. The separation of the active ingredient and its purification was performed using both thin layer (TLC) and column chromatography techniques. The physico-chemical characteristics of the purified antibacterial agent viz. color, melting point, solubility, elemental analysis, spectroscopic characteristics and assay of total phenolics have been investigated.

An imperical formula of Zingber officinale a suggested empirical formula of C11 H19 O8N which was evaluated as an antibacterial agent against $A$. hydrophila organism.

\section{INTRODUCTION}

Diseases pose a serious problem for the development of aquaculture especially for bacterial diseases that cause massive fish mortalities. Motile Aeromonas septicemia (MAS) cause $13-22 \%$ mortalities in catfish (Duarte et al., 1983) and cause $80 \%$ mortalities in Tilapia (Plumb 1999 and Shoemaker et al., 2000). MAS. affects fresh- water, occasionally brackish water and marine ( Azad et al., 2001). Aeromonas hydrophila is a common water borne bacterium, which may be present in the tissues of apparently normal fish (Bullock and Sniesko,1996). Aeromonas hydrophila is considered as an opportunistic pathogen for human causing soft tissue wound and diarrhea (Altwegg and Geiss, 1989). The risk associated with use of chemical and antibacterial agent may lead to increase antibiotic resistant bacteria, increase human infection and increase of residue, which may cause toxic and allergic 
reactions (Dixon,1994). Herbs can be used in treatment of bacterial diseases in aquatic animals. They contain natural products, which are usually safe for consumers. Many kinds of herbs may be used, including "Zingber officinale". The antimicrobial substances extracted from herbs are newly used for the treatment of bacterial diseases of fish. Consequently, interest has been focused on alternatives to chemicals particularly for best and disease control. The use of natural products from medicinal plant extracts for disease control are considered as one of the strategies available but much experimental work is being carried out to assess their commercial applicability (Kosar et al., 2005).

Zingber plants belonging to different species and ecotypes (biotypes) are widely used in agriculture and the pharmaceutical and cosmetic industries as a culinary herb, flavoring substances of food products, alcoholic beverages and perfumery for their spicy fragrance. It has been also used as a traditional remedy to treat various ailments such as a spasmodic, antimicrobial, expectorant, carminative and aromatic for whooping and convulsive coughs, digestive disorders and menstrual problems (Aligiannis et al., 2001). In previous studies, it has been demonstrated that the content of essential oil and extracts of medicinal plants like Zingber species containing antibacterial activities on many bacteria, namely (Escherichia coli, Staphylococcus aureus, (Sahin et al., 2004). Antioxidant and other biological activities may be changed based on the deference's in cultivation, origin, vegetative stage and growing seasons of the plants (Deans et al., 1992). The chemical compositions of Zingber officinale subspecies are caryophyllene, spathulenol, germacrene-D and a terpineol (Sahin et al., 2004). From the aforementioned data, this study was planned to study the effect of the pure extract of Zingber officinale as antimicrobial agent on the causative agent of Motile Aeromonas Septicaemia in freshwater fish .

\section{MATERIALS AND METHODS}

Naturally infected fish: A total number of 100 O. niloticus weighting $80 \pm 5 \mathrm{~g}$ were collected from ponds of Central Laboratory for Aquaculture Research, Abbassa, Sharkia, Egypt. The collected samples were subjected to full clinical and postmortem examinations according to methods described by Plumb and Bowser (1983).

\section{Bacteriological examinations:-}

The samples were collected under aseptic condition from the affected lesions (skin ulcer, tail and fins, gills, liver, kidney, spleen and ascitic fluid), then inoculated into tryptic soy broth (Difco) and incubated at $29^{\circ} \mathrm{C}$ for $24 \mathrm{hrs}$. The growing colors were then streaked on Aeromonas base agar with supplement (ampicillin) (Biolife). Pure colonies were inoculated on nutrient agar slant for further identification by standard microbiological procedures according to Schaperclaus et al. (1992).

\section{Experimental infection:}

A total of 30 apparently healthy $O$. niloticus were collected from Central Laboratory for Aquaculture Research . Fish were acclimatized to laboratory condition for 2 weeks in glass aquaria. The $O$. niloticus were divided into 3 groups, each group contains 10 fish as shown in Table (3). The isolated Aeromonas hydrophila was injected I/P with a dose of $0.2 \mathrm{ml}$ of $24 \mathrm{hr}$ broth culture $\left(5 \times 10^{5} \mathrm{cfu}\right)$ according to the methods described by Schaperctaus et al. (1992).

\section{Antibiogram sensitivity:-}

Antibiogram sensitivity was performed using different chemotherapeutic agents. The test was conducted according to method described with Quinn et al. (1999) using Amoxicillin. Ciprofloxacin, Tetracycline, Nalidixic acid, Ampicillin and streptomycin . 


\section{Plant materials:-}

Rhizomes of Zingber officinale were collected from South Sinai. Rhizomes of Zingber officinale was dried at room temperature, powdered and kept in plastic bags until extraction.

\section{Screening for antibacterial activity:}

The antibacterial activity was determined according to Kavanagh (1972).

\section{The extract of Zingber officinale was tested against standard Gram positive and Gram negative bacteria as follow:}

1-Gram positive: Staphylococcus aureus.

2- Gram negative: Escherichia coli.

Also, the extract was tested as specific for fish pathogen A. hydrophila, which was locally from naturally infected freshwater fish .

\section{Extraction of the plant organs :-}

The coarsely powered shoot parts of Zingber officinale (200 gms) were extracted with distilled water, $95 \%$ ethanol and then partitioned using ethyl acetate and chloroform for 6 hours in a Soxhlet, after which the extract was filtered using Whatman filter paper No. 1 after cooling. The excess solvent of crude and partition of aqueous and organic extract was removed under vacuum using rotary evaporator. Each extract was kept in refrigerator for further biological investigation.

\section{Precipitation: -}

The precipitation process of the antibacterial agent was carried out using petroleum ether. The compound precipitate was centrifuged at $5000 \mathrm{rpm}$ for $15 \mathrm{~min}$. The antibacterial agent powder was tested for its antibacterial activity by using tube dilution.

\section{Separation:-}

Separation of the antibacterial agent into its individual components has been carried out by thin layer chromatography using a solvent system composed of chloroform and methanol $(24: 1, v / v)$.

\section{Purification: -}

The purification of the antibacterial agent was carried out by using Silica Gel Column Chromatography. A column of $2.5 \times 50 \mathrm{~cm}$ was used for this purpose. Chloroform and methanol 10:1 (v/v), was used as an eluting solvent. The column was left for over night until the silica gel (BDH - 60- 120 mesh) was completely settled. One-ml crude extract to be fractionated was added on the silica gel column surface and the extract was adsorbed on top of silica gel column. Fifty fractions were collected (each of $5 \mathrm{ml}$ ). Antibacterial activities were performed for each separate fraction.

\section{Assay for total phenolics:-}

Total phenolic constituent of the methanol extract of Zingber officinale was determined by employing the methods given in the literature of Slinkard and Singleton (1997) involving Folin - Ciocalteu reagent and gallic acid as standard.

\section{Physico-chemical properties of antibacterial agent:-}

1- Elemental analysis: The elemental analysis C, H, O, N, and S was carried out by the microanalytical center of Al-Azhar University, Egypt. 
2- Spectroscopic analysis: The IR, UV, Mass spectrum , NMR-Spectrum and GC/mass were determined at the micro analytical mycology center of Al-Azhar University, Egypt.

\section{RESULTS AND DISCUSSION}

The results of clinical examination of the moribund $O$. niloticus revealed loss of appetite, loss of balance, swimming near to the water surface, scales losses behind the head and roughed scales. As result of toxicamia, vasoconstriction in blood vessles .These results agree with those mentioned by Shoemaker et al. (2000); Cipriano, (2001); El-Ashram, (2002); Abou El-Atta, (2003) and Abou El-Atta and Wafeek, (2005). Also, hemorrhage at the fin bases and most parts of the body, slight exophthalmia (Photo.1) and fryed and sloughed tail and fins rot (Photo. 2) were recorded. Internally, enlarged liver, congested spleen and kidney, distended gallbladder with bile due to constriction of the bile ducts as a result of hepatomegaly were seen. These results accepted with those mentioned by Shoemaker et al. (2000); Cipriano, (2001); El-Ashram, (2002) and Abou El-Atta, (2003). In addition, the intestine was free from any food particles, these lesions may be due to bacterial toxins which secreted by bacteria (Photo. 3).

\section{Results of bacteriological examination:-}

According to morphological and biochemical characters shown in Table (1), the isolated bacteria was proved to be Aeromonas hydrophila. It is Gram - ve, short rods $0.3 \times 1.0-$ 3.54 , rapid growth rate colonies within $24 \mathrm{hr}$ at $29^{\circ} \mathrm{C}$ help its ubiquity. These results were almost similar to those described by Enany et al. (1985); Roberts, (1989); Plumb, (1999); El-Ashram, (2002) and Abou El-Atta, (2003). The prevalence and distribution of Aeromonas hydrophila in different organs and tissues of O. niloticus shown in Table (2) where the higher percentage of distributions in skin ulcer and tail and fins with $16.90 \%$ and $16.54 \%$ respectively while lowest percentage were recorded from spleen and ascitic fluid 10.21 and $12.32 \%$ respectively . The higher prevalence of $A$. hydrophila could be attributed to its presence as a part of intestinal flora of healthy fresh water fish and marine water fish (Newman, 1982). The highest recovery rate of $A$. hydrophila from skin ulcer, fins and tail may be attributed to the primary entrance of systemic infection, these results agree with Enany et al. (1985); Azad et al. (2001); El-Ashram (2002) and Abou El-Atta (2003) and Enany et al. (2011) .

\section{Results of experimental infection:-}

Injected fish showed nearly similar clinical signs and postmortem lesions to natural infected fish. The mortality rate among artificial infected fish showed in Table (3). The intraperitoneal (I/P) route of injection appear to be more pathogenic than the intramuscular (I/M) route. 
Table (1): Important morphological and biochemical characters of A. hydrophila

\begin{tabular}{|c|c|}
\hline Test & Reaction \\
\hline Motiliy & + \\
\hline Gram staining & G-Ve \\
\hline Gelatin liquefaction & + \\
\hline Oxidase & + \\
\hline $\mathbf{O} / \mathbf{F}$ & $\mathbf{F}$ \\
\hline Growth on $5 \% \mathrm{NaCl}$ & - \\
\hline Indole formation & + \\
\hline V.P & + \\
\hline Methyl red reaction & + \\
\hline H2S production & - \\
\hline Catalase formation & + \\
\hline Nitrate reduction & + \\
\hline Citrate utilization & + \\
\hline Arginine hydrolysis & + \\
\hline \multicolumn{2}{|l|}{ Fermentation of :- } \\
\hline D-Glucose & + \\
\hline Sucrose & + \\
\hline Lactose & - \\
\hline Maltose & + \\
\hline D-Galactose & + \\
\hline D-Fructose & + \\
\hline Trehalose & + \\
\hline
\end{tabular}

Table (2): Distribution of Aeromonas hydrophila in different tissues and organs of clinically diseased Tilapia niloticus .

\begin{tabular}{|c|c|c|c|c|c|c|c|c|}
\hline Fish species & $\begin{array}{c}\text { Organ } \\
\rightarrow\end{array}$ & $\begin{array}{c}\text { Skin } \\
\text { ulcer }\end{array}$ & $\begin{array}{c}\text { Tail } \\
\text { \&Fin }\end{array}$ & Gill & Liver & Kidney & Spleen & $\begin{array}{c}\text { Ascitic } \\
\text { fluid }\end{array}$ \\
\hline Tilapia & No & 48 & 47 & 39 & 41 & 45 & 29 & 35 \\
\cline { 2 - 9 } nilotica & $\%$ & 16.90 & 16.54 & 13.73 & 14.43 & 15.84 & 10.21 & 12.32 \\
\hline
\end{tabular}

Table (3): Mortality rate among Tilapia nilotica inoculated with Aeromonas hydrophila.

\begin{tabular}{|c|c|c|c|c|c|c|}
\hline $\begin{array}{c}\text { Fish } \\
\text { species }\end{array}$ & Group & $\begin{array}{l}\text { Route of } \\
\text { injection }\end{array}$ & $\begin{array}{l}\text { Type and dose of } \\
\text { injected material }\end{array}$ & $\begin{array}{c}\text { No of } \\
\text { injected } \\
\text { fish }\end{array}$ & $\begin{array}{c}\text { No of } \\
\text { Dead fish }\end{array}$ & $\begin{array}{c}\text { Mortality } \\
\%\end{array}$ \\
\hline \multirow{3}{*}{$\begin{array}{l}\text { Tilapia } \\
\text { nilotica }\end{array}$} & I & I.P. & $\begin{array}{l}\mathrm{o} .2 \mathrm{ml} \text { of } 5 \times 10^{5} \mathrm{cfu} \text { of } \\
\text { Aeromonas hydrophila }\end{array}$ & 10 & 9 & 90 \\
\hline & II & I.M. & $\begin{array}{l}\mathrm{o} .2 \mathrm{ml} \text { of } 5 \times 10^{5} \mathrm{cfu} \text { of } \\
\text { Aeromonas hydrophila }\end{array}$ & 10 & 8 & 80 \\
\hline & III & I.P.+I.M. & $0.2 \mathrm{ml}$ of sterile broth & $5+5$ & $\mathbf{0}$ & $\mathbf{0}$ \\
\hline
\end{tabular}




\section{Results of antibiogram sensitivity test:-}

The antibiogram sensitivity test revealed that Aeromonas hydrophila was sensitive to ciprofloxacin $\left(\mathrm{CIP}_{5}\right)$ at a concentration of $5 \mathrm{mg}$ as shown in Photo. (4). These results were reported also by Abou El-Atta and Wafeek (2005); Abou El Atta et al. (2010) and Enany et al. (2011) .

\section{Control of pathogenic bacterial growth using Zingber officinale:}

The antibacterial substance produced by Zingber officinale exhibited various degrees on inhibitions of $A$. hydrophila growth (Table 4) and Photo (5).

\section{Extraction, Precipitation and Purification of antibacterial activities:-}

The coarsely powered rhizomes of Zingber officinale (200 g) were extracted with 95 $\%$ ethanol for 6 hours in a Soxhlet, then the extract was filtered using Whatman filter paper No. 1 after cooling. The excess of crude extract was evaporated under vacuum using rotary evaporator. The residual syrup was dissolved in a least amount of DMSO and filtered. The filtrates were tested for their antibacterial activity (Table 5). The coarsely powered rhizomes of Zingber officinale ( $200 \mathrm{~g}$ ) were extracted with $95 \%$ ethanol for 6 hours in a Soxhlet, then the extract was filtered using Whatman filter paper No. 1. Similar results were recorded by Anna et al., (2004). Only one fraction was obtained with petroleum ether (b.p. $40-60^{\circ} \mathrm{C}$ ) by centrifugation at $5000 \mathrm{rpm}$ for 15 minute. Crude deep green powder was tested for their antibacterial activities by using cup diffusion method. Separation of the antibacterial agent into individual components has been carried out by thin layer chromatography (TLC).

The obtained results revealed two bands at $R_{f} 0.76$ and 0.76 . One band at $R_{f} 0.76$ exhibited obvious inhibitory effects against the growth the used bacterial strains.

The purification of the antibacterial substance was carried out by using silica gel column chromatography. The active fractions were concentrated. The maximum activity was recorded at fraction No. 9\&10 (Table 6). These results were similar that reported by Tohamy et al. (2006)

The excess of crude extract evaporated under vacuum using rotary evaporator. The extract was concentrated and treated with petroleum ether (b.p. $40-60^{\circ} \mathrm{C}$ ) for precipitation process where only one fraction was obtained in the form of deep green ppt.

Separation of antibacterial substance into individual components has been tried by thinlayer chromatography using a solvent system composed of chloroform and methanol (24:1, $\mathrm{v} / \mathrm{v}$ ) as developing solvent. The band with $R_{\mathrm{f}}$ value of 0.76 there is one band at $R_{\mathrm{f}} 0.76$ exhibited obvious inhibitory effects against the growth bacteria strains. For the purpose of purification process, the antibiotic were allowed to pass through a column chromatography packed with silica gel and eluting solvent was composed of chloroform and methanol (10:1, $\mathrm{v} / \mathrm{v})$, where fifty fractions were collected and tested for their activities. The maximum activity was recorded at fractions No. 9\&10. Similarly, many workers used a column chromatography packed with silica gel and an eluting solvent composed of various ratios of chloroform and methanol. Similarly; (Yoko et al., 2001; Ueno et al., 2002),

\section{Physico-Chemical properties of the Secondary plant metabolites:}

The physico-chemical characteristics of the purified antibacterial substance revealed that, the melting point are $175^{\circ} \mathrm{C}$ and soluble in, ethanol, water, chloroform, DMSO and methanol but insoluble in, petroleum ether, n-Butanol, hexane and benzene. Similar results were recorded by Ueno et al. (2002); Anna, et al. (2004); Sahin et al. (2004) and Kosar et al. (2005). 


\section{A-Elemental analysis:}

The elemental analytical data of the antimicrobial agent indicated that: $\mathbf{C}=46.31 ; \mathbf{H}=6.31 ; \mathbf{N}=4.85 ; \mathbf{O}=42.53$ and $\mathbf{S}=0.0$

This analysis indicate a suggested empirical formula of: $\boldsymbol{C}_{11} H_{19} \boldsymbol{O}_{8} N$.

The spectroscopic characteristics of the antibacterial substance revealed the presence of the maximum absorption peak using UV. at $188 \mathrm{~nm}$, infra-red absorption spectrum represented by 22 peaks and Mass-spectrum revealed that the molecular weight was 294 Dalton .

\section{B- Spectroscopic characteristics:}

The ultraviolet (UV) absorption spectrum of the antibacterial substance recorded a maximum absorption peak at $188 \mathrm{~nm}$ (Fig.1). The infrared (IR) spectrum of the antibacterial agent exhibited characteristic band corresponding to 22 peaks (Fig.2). The Mass spectrum of antibacterial agent revealed that the molecular weight at 294 (Fig.3) and NMR-spectrum has been also investigated (Fig. 4) and GC/mass (Fig. 5) .

\section{Total of phenolic compounds:}

Based on the absorbance value of the methanol extract solution, reacted with Folin Ciocalteu reagent an compared with the standard solutions of gallic acid equivalents as described above, the amount of total phenolics was estimated as $235 \mathrm{ug} / \mathrm{ml}$ dry extract $(24 \%, \mathrm{w} / \mathrm{w})$. The amount of total phenolics constituent of the methanol extract of O.vulgare was estimated as $235 \mathrm{ug} / \mathrm{ml}$ dry extract $(24 \%$, w/w). Similar results were recorded by Sahin $\boldsymbol{e t}$ al. (2004).

\section{C- Biological activities of the purified secondary plant metabolites :-}

Data of the antibacterial spectrum of the secondary plant metabolites indicated that the antibacterial agent is fairly active against Gram-positive and Gram negative bacteria (Table7). The MIC of the antibacterial agent under study exhibited various activities against Gram positive and Gram-negative bacteria. Similar investigations and results were attained by Atta et al. (2003); Sahin et al. (2004); Kosar et al. (2005) and Tohamy et al. (2006).

\section{CONCLUSION:}

From the results mentioned above the antibacterial agent extracted from Zingber officinale can be used for control of bacterial diseases caused by Gram positive and Gram negative bacteria instead of the chemical antibiotics for their safety for human and environment.

Table (4): Mean diameters of inhibition zones (mm) caused by $100 \mu \mathrm{l}$ of the antibacterial activities from Zingber officinale in the agar plate diffusion assay

\begin{tabular}{|l|l|}
\hline Test organism & $\begin{array}{l}\text { *Mean diameters of inhibition zones } \\
(\mathbf{m m})\end{array}$ \\
\hline Aeromonas hydrophila & \multicolumn{1}{|c|}{32} \\
\hline
\end{tabular}


Table (5): Extraction of antibacterial substance of Zingber officinale :-.

\begin{tabular}{|l|c|}
\hline \multirow{2}{*}{ Extract Type } & *Mean diameters of inhibition zones (mm) \\
\cline { 2 - 2 } & Aeromonas hydrophila \\
\hline Crude aqueous extract & $\mathbf{0 . 0}$ \\
\hline Ethyl Acetate & $\mathbf{1 0}$ \\
\hline Ethyl Alcohol & 33 \\
\hline Acetone & $\mathbf{2 8}$ \\
\hline Chloroform & $\mathbf{0 . 0}$ \\
\hline
\end{tabular}

* Mean values of 3 determinations.

Table (6): Isolation, precipitation and purification steps of antibacterial substance from Zingber officinale:-

\begin{tabular}{|l|c|}
\hline \multirow{2}{*}{ Step } & *Mean diameters of inhibition zones (mm) \\
\cline { 2 - 2 } & Aeromonas hydrophila \\
\hline 1-Isolation & $32 \pm 0.15$ \\
\hline 2-Precipitation & $31 \pm 0.20$ \\
\hline $\begin{array}{l}\text { 3-Purification by Column } \\
\text { chromatography }\end{array}$ & $28 \pm 0.23$ \\
\hline
\end{tabular}

* Mean values of 3 determinations.

Table (7): Antibacterial spectrum of the Purified antibacterial substance:-

\begin{tabular}{|c|c|c|}
\hline Organism & Code & $\mathrm{MIC}(\mu \mathrm{g} / \mathrm{ml})$ concentration \\
\hline \\
\hline Staphylococcus aureus, & NCTC 7447 & 11.7 \\
\hline \multicolumn{3}{|l|}{ 2-Gram Negative Bacteria } \\
\hline Escherichia coli & NCTC 10416 & 23.4 \\
\hline \multirow{2}{*}{$\begin{array}{l}\text { 3-Bacteria isolated from Fish } \\
\text { Aeromonas hydrophila }\end{array}$} & & \\
\hline & & 60.5 \\
\hline
\end{tabular}




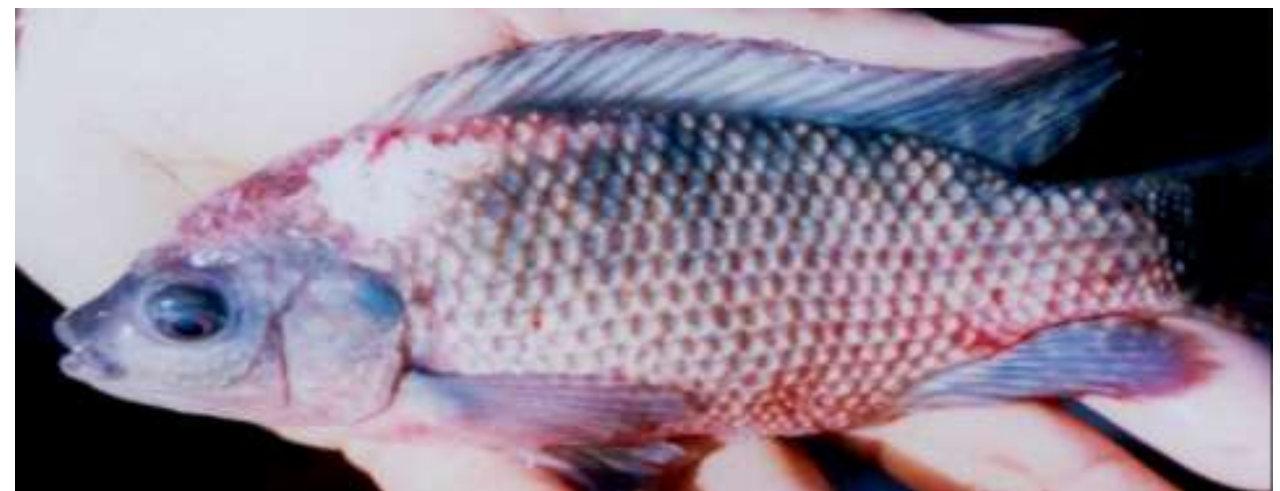

Photo (1): O. niloticus clinically showed scale losses behind the head, roughed scales, haemorrhage at the base of the fin and slight exophthalmia.

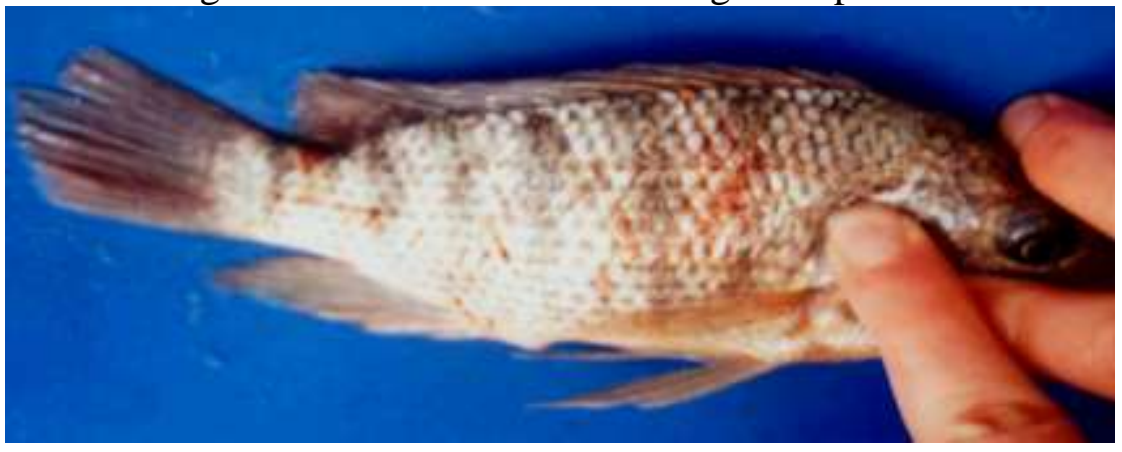

Photo (2) : O. niloticus clinically showed fryed \& Sloughed taill and fin rot .

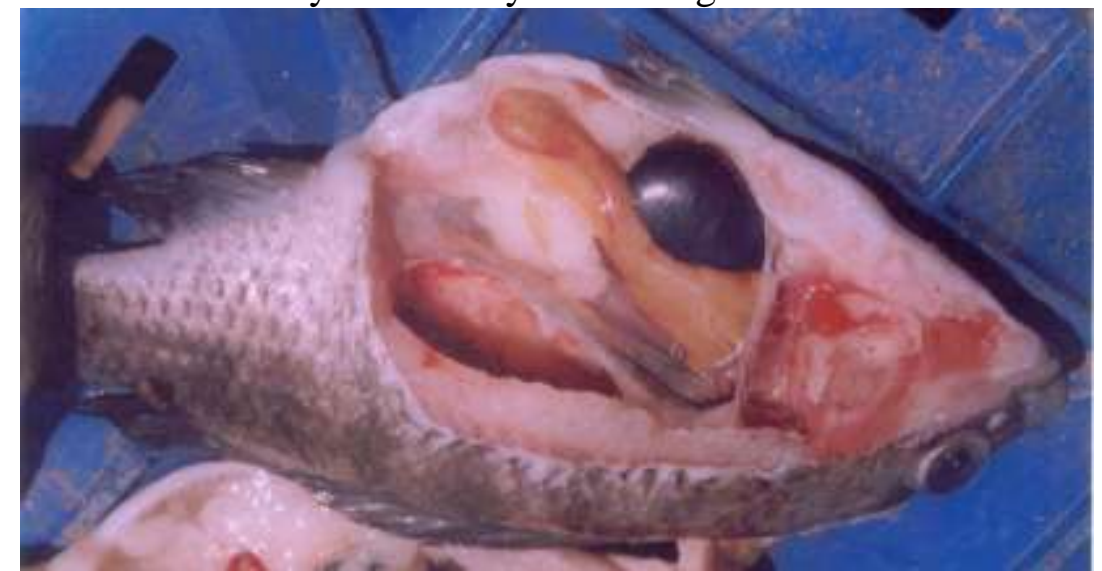

Photo (3) : $O$. niloticus internally showed enlarged liver, gall bladder, congested kidney and spleen .

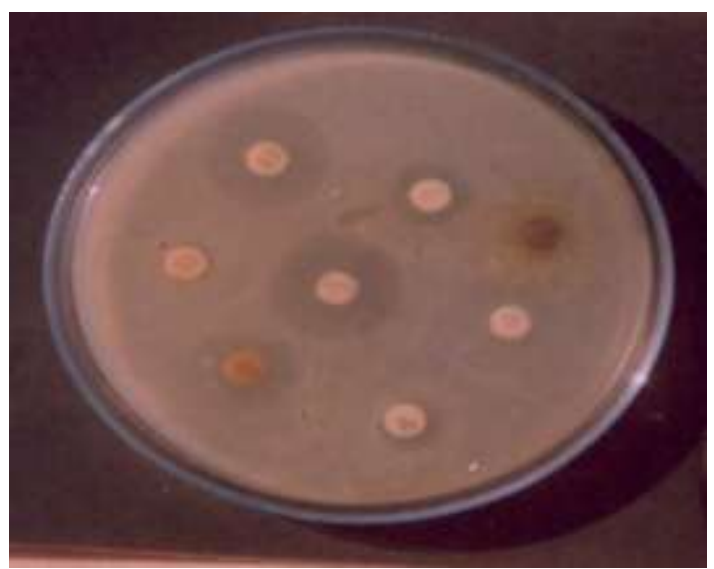

Photo (4) : Antibiogram sensitivity test showed zone of inhibition around the antibiotic discs 


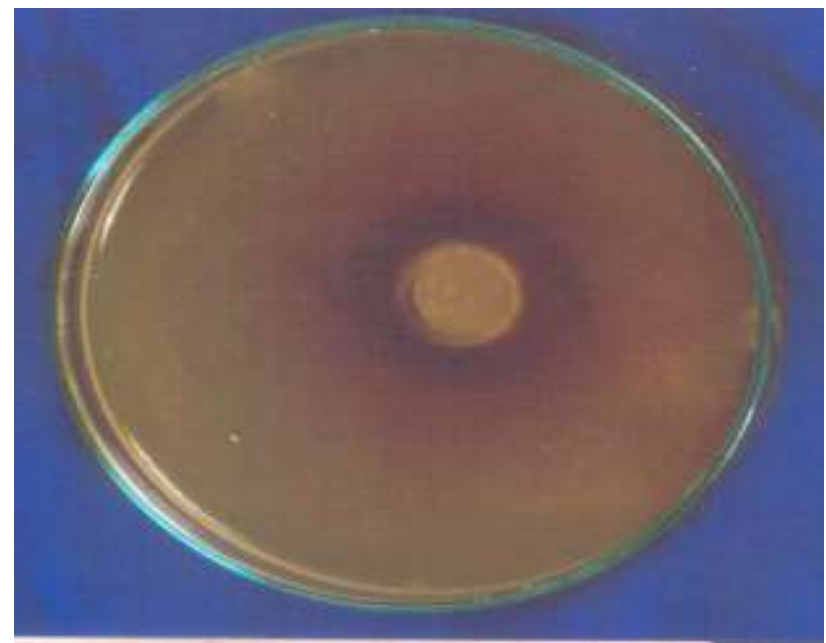

Photo (5) : The antibacterial substance produced from Zingber officinale exhibited various degree of inhibition on A. hydrophila growth .

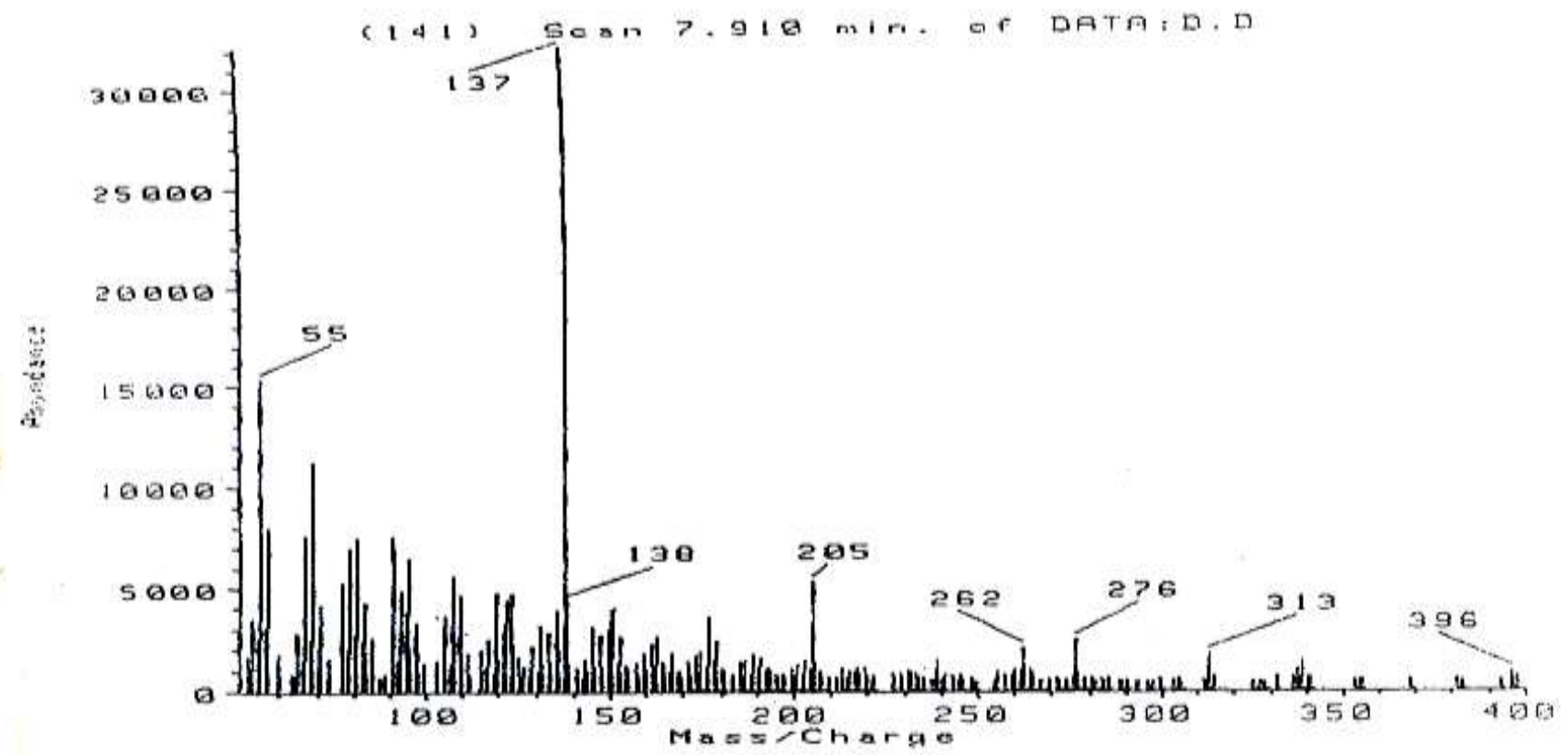

Fig. (1): The mass spectrum of the purified antimicrobial substance produced by Zingebare officienale.

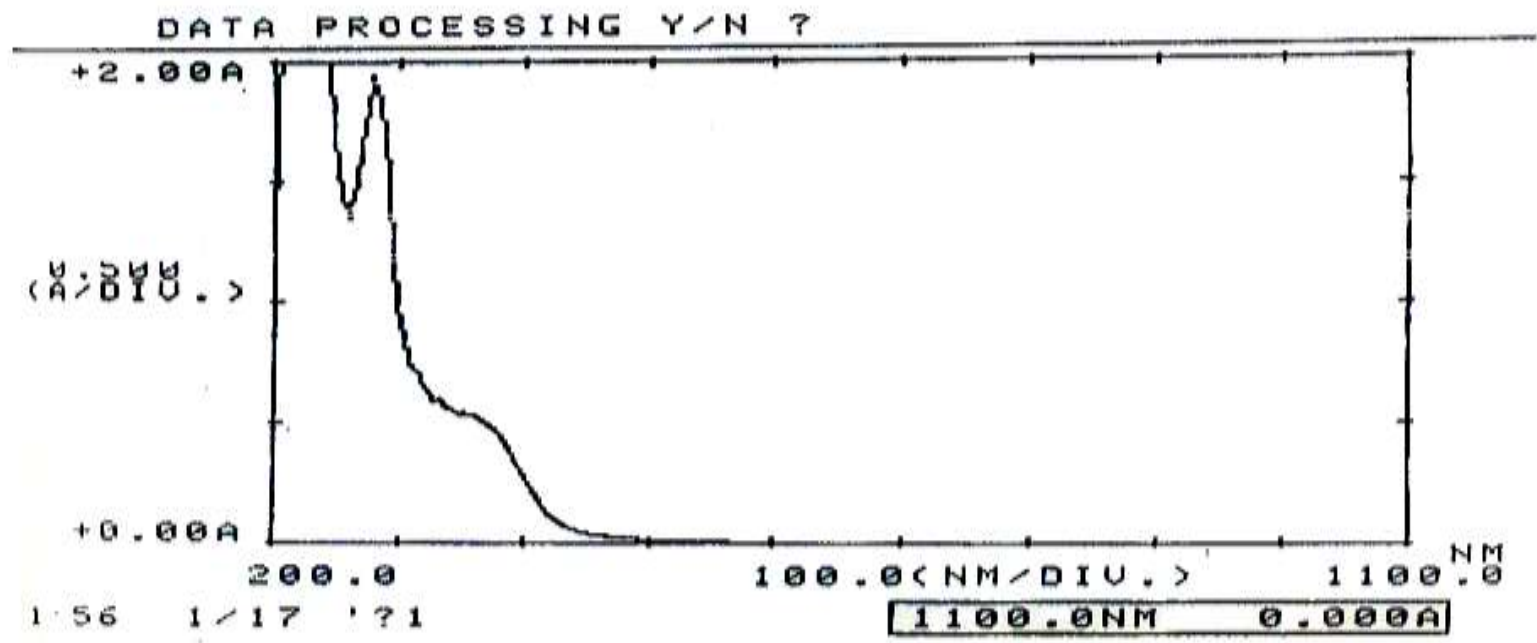

Fig. (2) : The UV spectrum of the antimicrobial substance produced by Zingebare officinale. 


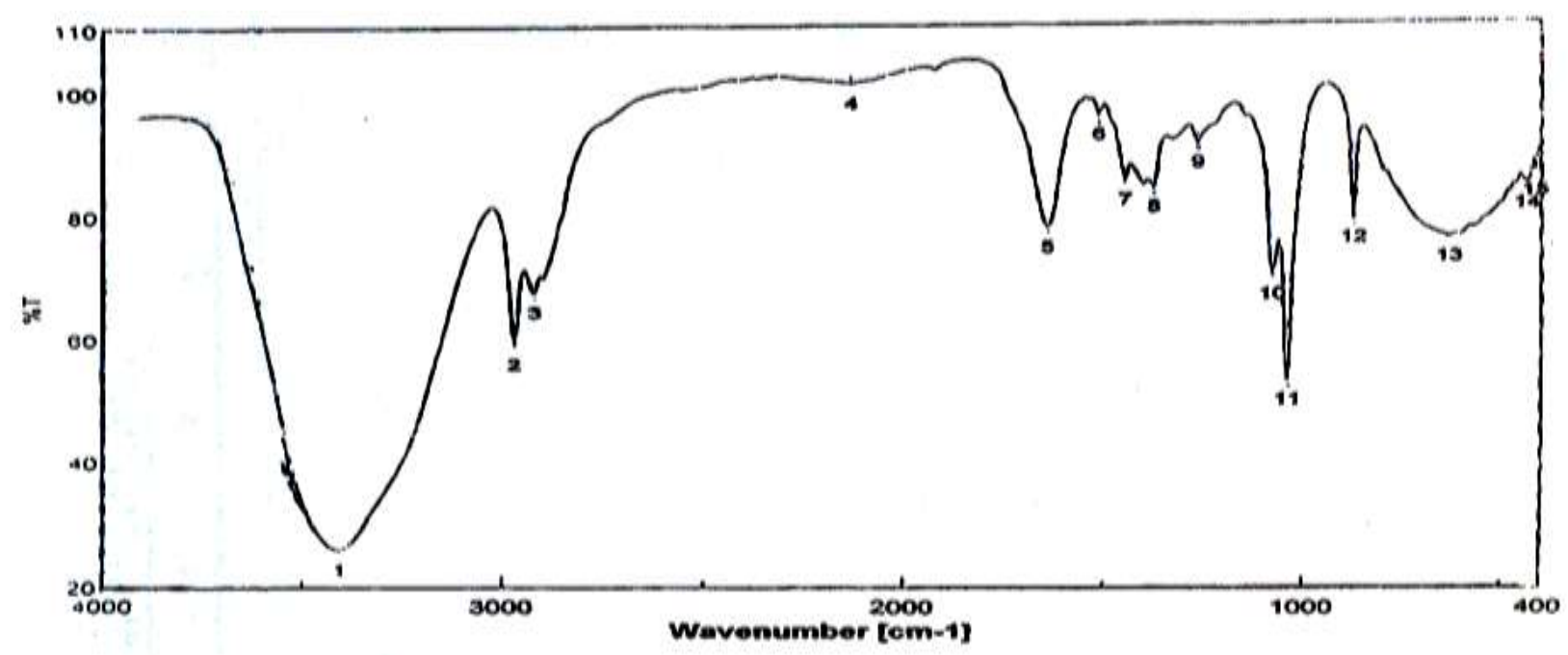

Fig. (3): The IR spectrum of the antimicrobial substance produced by Zingebare officinale.

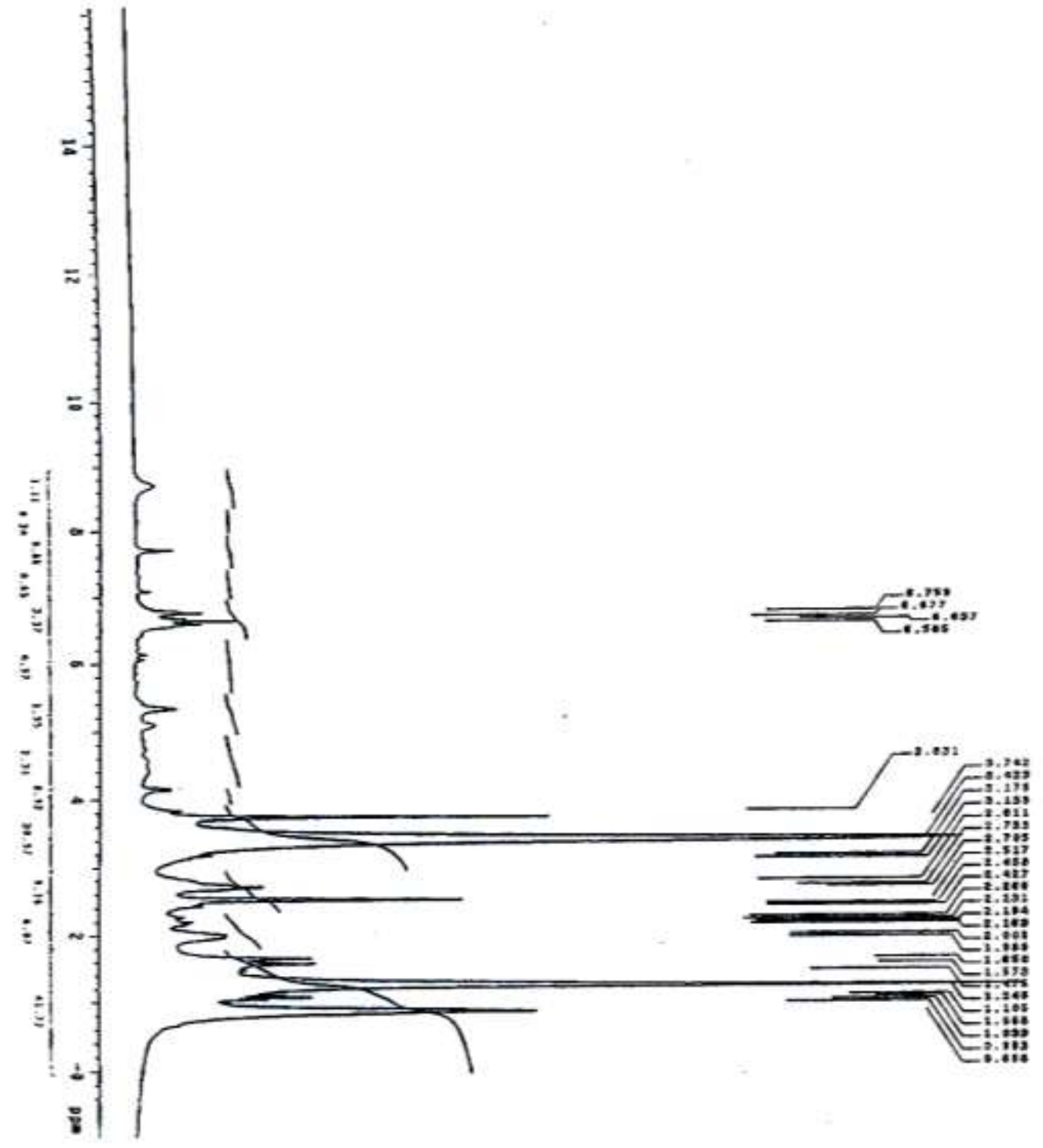

Fig. (4): The NMR spectrum of the antimicrobial substance produced by Zingebare officinale 


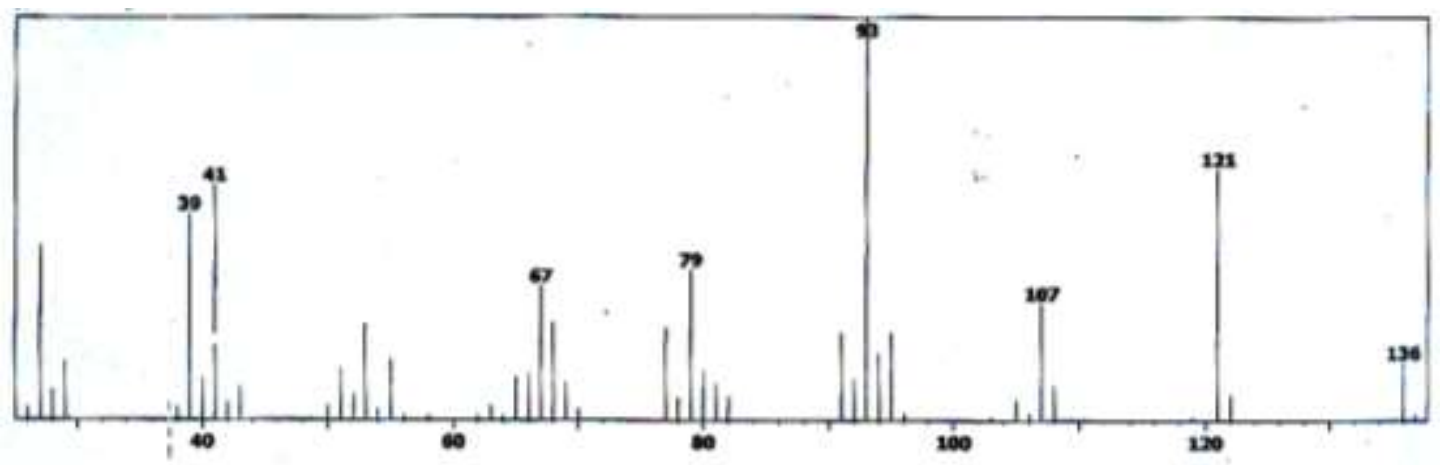

Fig. ( 5 ) : The Gas Chromatography Mass Spectroscopy of the Antimicrobial Substance Produced by Zingebare offivinale

\section{REFERENCES}

Abou El-Atta, M. E. (2003): Efficiency of polymerase chain reaction "PCR" in diagnosis of some bacterial fish pathogens Ph.D. Thesis (Microbiology) Fact. of Vet. Med., Suez Canal University.

Abou El-Atta, M. E and Wafeek, M. (2005): "Effect of water temperature on appearance of bacterial diseases and their reflection on biochemical changes in Oreochromis niloticus at Damietta branch of the river nile. Egypt. J. Aquat. -Biol. \&Fish. Vol. 9, No. 4:353-366.

Abou El-Atta M. E.and Saleh O.A (2010): A study on some Diseases problems the Culturing of Meagre (Argyrosomus regius) Fish in Damieta Governorate - Egypt . Abbassa . Aqua. Vol. No. (1) 2010. pp.( 231-245).

Aligiannis, N., Kalpoutzakis, E., Mitaku,S. and Chinou, I. B. (2001): Composition and antimicrobial activity of the essential oils of two Origanum species. Journal of Agriculture Food Chemistry. 49:4168 -4170 .

Altwegg, M. and Geiss, H. K. (1989): "Aeromonas as a human pathogen . Critical reviews in Microbiology, 16:253-286.

Anna, M., Marina K., Mihkel J., and Anne O. (2004): Identification and characterization of supercritical fluid extracts from herbs. C.R. chimie 7 (628-633).

Atta, H. M.; Abul-Hamd, A. T. and Zain, M. E. (2003): Fermentation, Extraction, Physicochemical Properities and Biological activities of the antifungal agent produced by Streptomyces aureofaciens. The african journal of mycology and biotechnology. Vol. 11(2) August: pp 51-67.

Azad, I. S; Rajendran, K. V.; Rajan, J. S.;Vijayan, T. C. and Santiago, T. C. (2001): Virulence and histopathology of Aeromonas hydrophila (SAH 93) in experimentally infected tilapia, Oreochromis mossambicus (L.). J. Aqua. Trop. 16 (3):265-275.

Bullock, G. L and Sniesko, S. F. (1996): Bacteria in blood and kidney of apparently healthy hatchery trout. Trans. Am. Fish. Soc. 98 268-271.

Cipriano, R. C. (2001): Aeromonas hydrophila and motile aeromonas septicemia of fish. J. Fish Dis. 68: 1-24

Deans, S. G., Svoboda, K. P., Gundidza, M., and Brechany, E. Y. (1992): Essential oil profiles of severe temperate and tropical aromatic plants: their antimicrobial and antioxidant activities. Acta Horticulture.306: 229 - 232. 
Dixon,B.A. (1994): "Antibiotic resistant of bacterial fish pathogens.Journal of world aquaculture society 25:60 63 .

Duarte, S. A., Masser. M. P. and Plumb, J. A. (1983): "Seasonal occurrence of diseases in cage reared channel catfish 1987-1991. Journal of Aquatic Animal Health 5, 223 229.

El-Ashram, A. M. (2002): On Aeromonas hydrophila infection among cultured tilapias :A biological, histopathological and management study. . J. Aquat. Biol. \&Fish. Vol. 6, No. 3:181-202.

Enany, M.; Nareeman, E. Abd El-Galil, Y. and Ammar, A. M. (1985): Aclinico-pathological study of aeromoniasis in experimentally inoculated Armout catfish . First Int. conf. App. Sci., 4: 1753-1767.

Enany M. E. Ibrahim H. M; Abou El Atta M. E. and El-adawy M. M (2011): Bacteriological and histopathological studies on some bacterial pathogens causing diseaseas in cultured Magil capito fish in ismailia Governorate . SCV MJ X VI (1) 2011 PP ( $1-10)$.

Kavanagh, F. (1972): Analytical Microbiology. Vol. 2 , Acad. Press, New York.

Kosar, M.; Dorman, H. and Hiltunen, R. (2005): Effect of an acid treatment on the phytochemical and antioxidant characteristics of extracts from selected Lamiaceae species. Food Chemistry 91, (525-533).

Newman, S. G. (1982): Aeromonas hydrophila: A review with emphasis on its role in fish diseases. In Antigens of fish pathogens. Development and production for vaccine and serodiagonositics, ed. D. P. Anderson, M. Dorson and Phdubouret, pp: 87-117 Lyon: foundation Marcel Merieux.

Plumb J. A and Bowser, P. R (1983): "Microbial Fish disease Laboratory Manual. Alabama Agriculture experimental Station Auburn University.

Plumb J. A (1999): Health maintenance and principal diseases of cultured fishes. Iowa Press. U.S. A.

Quinn P. J., Carter M. E., Markey B. K. and Carter G. R. (1999): Clinical Veterinary Microbiology Published by Wolf Publishing, Book Europe Limited.

Roberts, R. J. (1989): Fish pathology. SailliereTindal, London.

Sahin, F.; Guluce, M.; Daferera, D.; Sokmen , A.; Sokmen , M.; Polissiou, M.; Agar, G.; and Ozer, H. (2004): Biological activities of the essential oils and methanol extract of Origanum vulgare ssp. vulgare in the Eastern Anatolia region of Turkey. Food Control 15: (549-557).

Schaperclaus, W., Kulow, H. and Schreckenback, K. (1992): Fish Disease Vol.I A.A. Balkema / Rotterde.

Shoemaker, C. A.; Klesius, P. H. and Evans, J. J (2000): Disease of tilapia with emphasis on economically important pathogens $5^{\text {th }}$ Int. symposium on tilapia aquaculture in $21^{\text {th }}$ century, Brazil, 2:565- 572 .

Slinkard, K. and Singleton, V. L. (1997): Total phenol analyses automation and comparison with manual methods. American Journal of Enology and Viticulture, 28: 49 - 55. 
Tohamy E. Y., Atta. H. M., Hazah M., Abou El Atta . M. E and El Arabe D. A. (2006): Purification and characterization of an antibacterial agent from (Origanum vulgare) against of some pathogenic bacteria isolated from fishes. Egypt. J. Biotechnol. Vol. 22, February, 2006.p . 348-366.

Ueno, R., Urano, N., Suzuki, M., and Kimura, S. (2002): Isolation, characterization, and fermentative pattern of a novel thermotolerant Prototheca zopfii var. hydrocarbonea strain producing ethanol and $\mathrm{CO}_{2}$ from glucose at $40^{\circ} \mathrm{C}$. Arch. Microbiol. 177: 244-250.

Yoko, H., Masashi, U., Gen, O., Rie, O., Ron, U., Koki, H., and Hiroyuki, O. (2001): Isolation and Biological properties of a new cell cycle inhibitors curvularol, Isolation from curvulaia Sp RK97-F166. J. of antibiotics. 54 (1):10-16.

\section{كفاءة وصفات العامل المضاد للبكتريا المستخلص من نبات الزنجبيل ضد بكتريا إيروموناس هيدروفيلا

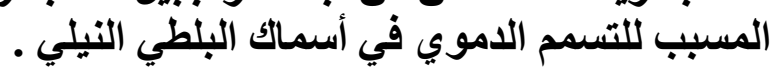 \\ بكري محمد هارون *؛ عصام حسين عبد الشكور * ، محمد السيد أبو العطا**؛ أحلام السيد عبد اللطيف****:فتحى

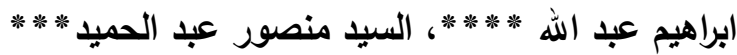

كلية العلوم جامعة الأزهر - قسم الميكروبيولوجي ؛ معمل بحوث الأسماك بالعباسة ؛معهذ صحة الحيوان بالزقازيق ، قسم الصيدلانيات والصيدلة الصناعية - كلية الصيدلة (بنين بالقاهرة) - جامعة الأزهر .

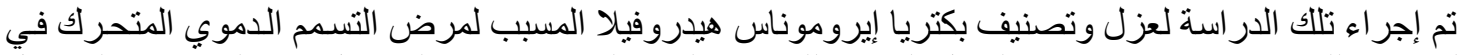
أسمالك البلطي وكذللك در اسة كفاءة وصفات العامل المضاد للبكتيريا المستخلص من نبات الزنجبيل ضد المبل الميكروب المعزول معمليا.

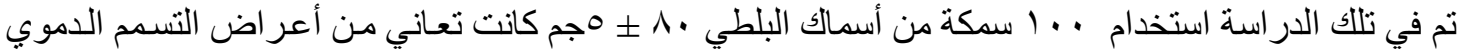

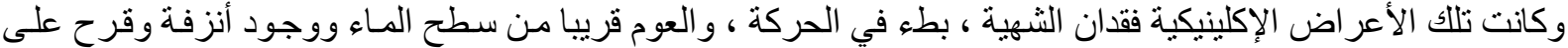

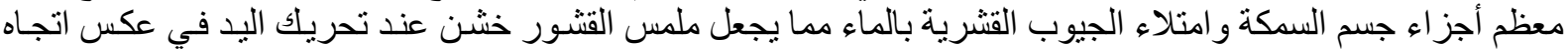

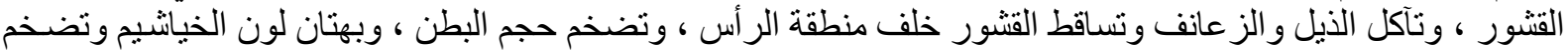

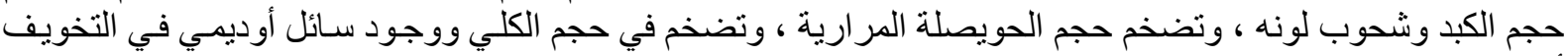
ألبطني.

ونتيجة للفحص البكتربولوجي للأسماك المصابة تم عزل وتصنيف ميكروب ايرومونساس هيدروفيلا من نتائج الصفات المورفولوجية و البيوكيميائية.

ووجد أن نسبة الإصابة في أسماك البلطي ^^؛ بنسبة ـ9.9 17\% وكانت أعلى نسبة لعزل البكتريـا من التقرحات الجلدية .

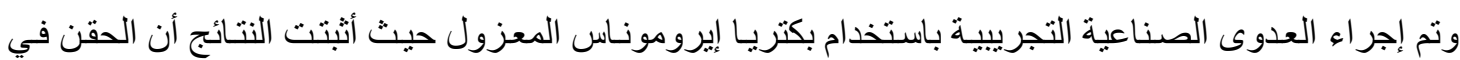

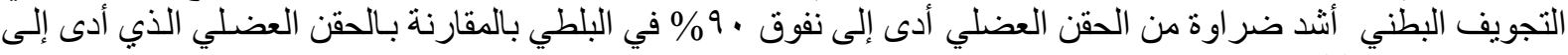

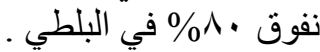

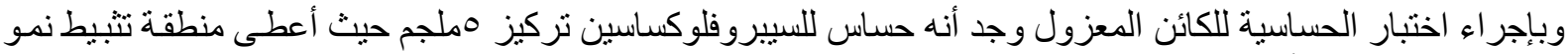

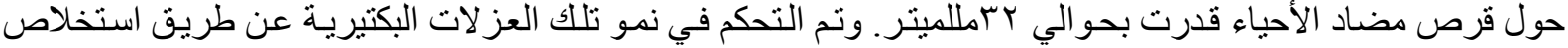

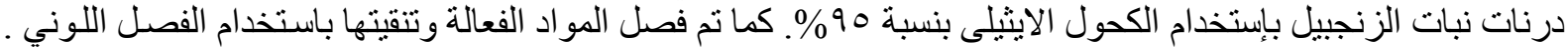

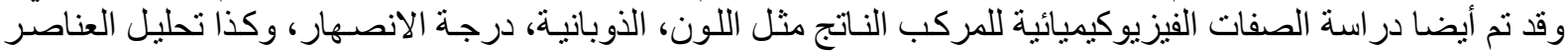
و الصفات الطيفية و الكمية (UV , IR , NMR, Mass Spectra GC/mass). حيث أفادت تلاتك التحاليل التيل إلى أن الصيغة الجزئية هي. 